Article

\title{
Retrospective Analysis of Six Years of Acute Flaccid Paralysis Surveillance and Polio Vaccine Coverage Reported by Italy, Serbia, Bosnia and Herzegovina, Montenegro, Bulgaria, Kosovo, Albania, North Macedonia, Malta, and Greece
}

\author{
Stefano Fontana ${ }^{1}$ D, Gabriele Buttinelli ${ }^{1}$ D , Stefano Fiore ${ }^{1}$, Concetta Amato ${ }^{1}$, Marco Pataracchia ${ }^{1}$, \\ Majlinda Kota ${ }^{2}$, Jela Aćimović ${ }^{3}$, Mia Blaževićc ${ }^{4}$, Mirsada Mulaomerović ${ }^{4}$, Lubomira Nikolaeva-Glomb ${ }^{5}$, \\ Andreas Mentis ${ }^{6}$, Androniki Voulgari-Kokota ${ }^{6}$, Luljeta Gashi ${ }^{7}$, Pranvera Kaçaniku-Gunga ${ }^{7}$, \\ Christopher Barbara ${ }^{8}$, Jackie Melillo ${ }^{9}$, Jelena Protic ${ }^{10} \mathbb{D}$, Svetlana Filipović-Vignjevic ${ }^{11}$, Patrick M. O'Connor ${ }^{12}$, \\ Alessandra D'Alberto ${ }^{13}$, Riccardo Orioli ${ }^{13}$, Andrea Siddu ${ }^{13}$, Eugene Saxentoff ${ }^{14}$ and Paola Stefanelli ${ }^{1, *}$
}

check for

updates

Citation: Fontana, S.; Buttinelli, G.; Fiore, S.; Amato, C.; Pataracchia, M.; Kota, M.; Aćimović, J.; Blažević, M.; Mulaomerović, M.;

Nikolaeva-Glomb, L.; et al.

Retrospective Analysis of Six Years of Acute Flaccid Paralysis Surveillance and Polio Vaccine Coverage Reported by Italy, Serbia, Bosnia and Herzegovina, Montenegro, Bulgaria, Kosovo, Albania, North Macedonia, Malta, and Greece. Vaccines 2022, 10 , 44. https://doi.org/10.3390/ vaccines 10010044

Academic Editor: Jorge H. Leitão

Received: 30 November 2021

Accepted: 24 December 2021

Published: 30 December 2021

Publisher's Note: MDPI stays neutral with regard to jurisdictional claims in published maps and institutional affiliations.

Copyright: (C) 2021 by the authors. Licensee MDPI, Basel, Switzerland. This article is an open access article distributed under the terms and conditions of the Creative Commons Attribution (CC BY) license (https:// creativecommons.org/licenses/by/ $4.0 /)$.
1 Department of Infectious Disease, Istituto Superiore di Sanità, 00161 Rome, Italy; stefano.fontana@iss.it (S.F.); gabriele.buttinelli@iss.it (G.B.); stefano.fiore@iss.it (S.F.); concetta.amato@iss.it (C.A.); marco.pataracchia@iss.it (M.P.)

2 Laboratory of Virology, Department of Control of Infectious Diseases, Institute of Public Health, 1001 Tirana, Albania; mdhimolea@live.com

3 Department of Epidemiology, Public Health Institute of the Republic of Srpska, 78000 Banja Luka, Bosnia and Herzegovina; jela.acimovic@phi.rs.ba

4 Institute for Public Health of Federation Bosnia and Herzegovina, 71000 Sarajevo, Bosnia and Herzegovina; m.blazevic@zzjzfbih.ba (M.B.); mirsada.mulaomerovic@gmail.com (M.M.)

5 Department of Virology, National Centre of Infectious and Parasitic Diseases, 1504 Sofia, Bulgaria; lubomira@gmail.com

6 National Poliovirus/Enterovirus Reference Laboratory, Diagnostic Department, Hellenic Pasteur Institute, 11521 Athens, Greece; mentis@pasteur.gr (A.M.); avoulgari@pasteur.gr (A.V.-K.)

7 Department of Epidemiology, National Institute of Public Health, 10000 Pristina, Kosovo; luljetagashi02@yahoo.com (L.G.); pranveragunga@hotmail.com (P.K.-G.)

8 Department of Pathology, Mater Dei Hospital, MSD2090 Msida, Malta; christopher.barbara@gov.mt

9 Department for Health Regulation, Health Promotion and Disease Prevention, MSD2090 Msida, Malta; jackie.m.melillo@gov.mt

10 National Reference Laboratory for ARBO Viruses and Hemorrhagic Fever, Institute of Virology, Vaccines and Sera “Torlak", 11152 Belgrade, Serbia; jprotic@torlak.rs

11 Diagnostics and Research and Development, Institute of Virology, Vaccines and Sera "Torlak", 11152 Belgrade, Serbia; sfilipovic@torlak.rs

12 Global Immunization Division US Centers for Disease Control and Prevention, Atlanta, GA 30333, USA; GYP8@cdc.gov

13 Prevention of Communicable Diseases and International Prophylaxis, Directorate General of Health Prevention, Ministry of Health, 00144 Rome, Italy; a.dalberto@sanita.it (A.D.); r.orioli@sanita.it (R.O.); a.siddu@sanita.it (A.S.)

14 Division of Health Emergencies and Communicable Diseases (DEC), Regional Office for Europe World Health Organization, DK-2100 Copenhagen, Denmark; saxentoffe@who.int

* Correspondence: paola.stefanelli@iss.it; Tel.: +39-06-4990-2126

Abstract: Here we analyzed six years of acute flaccid paralysis (AFP) surveillance, from 2015 to 2020, of 10 countries linked to the WHO Regional Reference Laboratory, at the Istituto Superiore di Sanità, Italy. The analysis also comprises the polio vaccine coverage available (2015-2019) and enterovirus (EV) identification and typing data. Centralized Information System for Infectious Diseases and Laboratory Data Management System databases were used to obtain data on AFP indicators and laboratory performance and countries' vaccine coverage from 2015 to 2019. EV isolation, identification, and typing were performed by each country according to WHO protocols. Overall, a general AFP underreporting was observed. Non-Polio Enterovirus (NPEV) typing showed a high heterogeneity: over the years, several genotypes of coxsackievirus and echovirus have been identified. The polio vaccine coverage, for the data available, differs among countries. This evaluation allows for the collection, for the first time, of data from the countries of the Balkan area regarding AFP surveillance 
and polio vaccine coverage. The need, for some countries, to enhance the surveillance systems and to promote the polio vaccine uptake, in order to maintain the polio-free status, is evident.

Keywords: enterovirus; poliovirus; non-polio enteroviruses; acute flaccid paralysis; poliovirus surveillance; polio vaccine coverage

\section{Introduction}

Human Enteroviruses (EVs), including polioviruses (PVs), are non-enveloped, positivesense single-stranded RNA viruses, transmitted via the fecal-oral route and respiratory tract. They are classified into four species (A, B, C, and D), with an increasing number of genotypes [1]. Although most EVs infections are asymptomatic, mild or severe diseases are reported in infants and in young children, such as self-limiting febrile illnesses, encephalitis, meningitis, acute flaccid paralysis (AFP), pancreatitis, myocarditis, encephalitis, and foot and mouth disease [1]. Among non-polio enteroviruses (NPEVs), EV-D68, EV-A71, and Echovirus genotypes can occur as an outbreak of infections with a relevant impact on public health [2-4]. EV-D68 in children can require intensive care support due to respiratory paralysis and a recent study reported epidemiological and biological evidence linking enterovirus D68 and acute flaccid myelitis [5,6]. EV-A71 has been associated with hand, foot and mouth disease and concurrent fatal encephalitis in very young children $[7,8]$. Echovirus 30 (E-30) is an emerging EV genotype, identified in most EV infections and often reported as responsible for meningitis $[9,10]$.

PV, classified within species C EVs, is the causative agent of Poliomyelitis (polio), a severe disease that affects mostly children under five years of age. The most common initial symptoms of polio are fever, headache, malaise, or aseptic meningitis. Although these symptoms usually last 2-10 days and most cases recover completely, PV infection can cause permanent paralysis of the limbs and, in a few cases, fatal breathing muscles immobility [11]. In 1988, the World Health Assembly adopted a resolution for the worldwide eradication of polio, marking the launch of the Global Polio Eradication Initiative (GPEI). Since then, the number of paralytic polio cases has fallen by over $99 \%$, from an estimated 350,000 to 140 reported cases in 2020 [12]. In June 2002, all WHO European Region Member States were certified as polio-free by the Regional Commission for the Certification of Poliomyelitis Eradication. High routine infant immunization coverage and acute flaccid paralysis (AFP) surveillance are part of the GPEI strategy and are considered essential components of the eradication plans. The number of AFP cases reported each year is used as an indicator of a country's ability to detect polio, even in countries where PVs do not circulate. A country's surveillance system needs to be sensitive enough to detect at least one case of AFP for every 100,000 children under 15 years of age [13]. Despite the usefulness and validity of AFP surveillance, many non-endemic countries have found it difficult to maintain high-sensitivity AFP surveillance in the absence of circulating PV and have adopted supplemental surveillance strategies to detect possible PV importations. Additional surveillance strategies and data have been accepted from countries with a long history of non-endemicity, high sanitation level, and strong health systems. These strategies include combinations of surveillance for polio cases and for cases of vaccine-associated paralytic poliomyelitis, environmental, and enterovirus surveillance [14]. Thanks to the GPEI, important milestones have been achieved in the fight against polio: wild poliovirus type 2 was eradicated in 1999 and no case of wild poliovirus type 3 has been reported since the last reported case in Nigeria in November $2012[15,16]$. Both type 2 and 3 wild type PV have officially been certified as globally eradicated. As of 2020, wild poliovirus type 1 affected two countries: Afghanistan and Pakistan [17]. Despite the success in achieving polio-free certification, some countries in the WHO European Region remain at high risk of possible polio outbreaks following importation, due, for instance, to a low population vaccine coverage and/or suboptimal surveillance performance, as demonstrated by the 
detection of two cases of polio due to circulating Vaccine-Derived Poliovirus (cVDPV) type 1 in Ukraine and the isolation in Bosnia and Herzegovina of one Sabin-like poliovirus type 2 strains, close to a VDPV $[18,19]$. The WHO Regional Reference Laboratory (RRL) at Istituto Superiore di Sanità (ISS) in Rome provides technical and scientific support for AFP surveillance activities in Serbia, Bosnia and Herzegovina, Montenegro, Bulgaria, Kosovo, Albania, North Macedonia, Malta, and Greece, and coordinates, together with the Italian Ministry of Health, the AFP surveillance in Italy. The RRL typically performs identification and characterization of polioviruses and other enteroviruses (EVs) from clinical specimens of AFP cases, provides reference materials, and trains personnel involved in laboratorybased surveillances activities. Hereby, six years of AFP surveillance data for 10 countries, including Italy, polio vaccination coverage, and EVs identification and typing, are reported.

\section{Materials and Methods}

\subsection{Study Setting}

Retrospective analysis of data collected in the period January 2015-December 2020, on the AFP cases reported by Italy, Serbia, Bosnia and Herzegovina, Montenegro, Bulgaria, Kosovo, Albania, North Macedonia, Malta, and Greece was performed by the RRL.

Data on AFP indicators and laboratory performance were obtained by the Centralized Information System for Infectious Diseases (CISID) database (https: / / data.euro.who.int/ cisid / ?TabID=543012 (accessed on 23 December 2021)).

Data on countries' vaccine coverage from 2015 to 2019, the number of samples analyzed in supplementary surveillance activities, and EVs isolation and typing data were obtained by the online Laboratory Data Management System (LDMS) of WHO/Europe (https: / / ldms.euro.who.int/Account/LogOn?ReturnUrl=\%2f (accessed on 23 December 2021)).

\subsection{AFP Surveillance and Performance Indicators}

AFP surveillance is considered, by the WHO, to be the gold standard for detecting polio cases. According to the WHO clinical case definition, any child under 15 years of age with AFP or any person of any age with paralytic illness, if polio is suspected, has to be investigated [13]. WHO recommendation provides that all AFP cases should be reported immediately and investigated within $48 \mathrm{~h}$ and that two stool specimens should be collected 24-48 $\mathrm{h}$ apart and within 14 days of the onset of paralysis. A country's surveillance system is expected to detect at least one case of AFP per 100,000 children under 15 years of age and it is recommended that a minimum $80 \%$ proportion of AFP cases have adequate stool specimens [13]. An AFP case has adequate samples if two stool specimens of sufficient quantity (8-10 g) are collected $24-48 \mathrm{~h}$ within 14 days of paralysis onset, and sent to the reference laboratory in good conditions [13].

According to the standard surveillance parameters recommended by the $\mathrm{WHO}$, data on the number of AFP cases notified, on the annualized rate per 100,000 children under the age of 15 , on the percentage of adequate stool specimens collected, on the surveillance index (SI) corresponding to a non-polio AFP rate up to $1.0 \times$ (percentage of adequate specimen), and on the age groups of cases were analyzed for each country.

\subsection{Vaccine Coverage, Supplementary Surveillances, EVs Identification and Typing}

Data on vaccine coverage in each country has been collected. Three doses of polio vaccine [oral polio vaccine (OPV) or inactivated polio vaccine (IPV)] administrated among children aged 12-23 months, for each year, were considered to determine the annual percentage of vaccine coverage for each country from 2015 to 2019. For each country, the presence of a supplementary surveillance, as EV and/or environmental surveillance, was verified, and the number of samples analyzed was also reported.

EV isolation, identification, and typing were performed by each country according to WHO protocols [20-22]. Data reported in the LDMS database were analyzed by number and relative percentage of EVs identified and typed by country and surveillance type. 


\section{Results}

\subsection{Indicators of AFP Surveillance and Laboratory Performance}

Table 1 reports data from six years of AFP surveillance data from 10 countries linked to the RRL in Rome. A total of 554 AFP cases were notified between 2015 and 2020 and for two thirds of them stool samples were collected within 14 days after symptoms' onset. Malta and Kosovo reported only one AFP case from 2015 to 2020. In 2016 the highest number of AFP cases $(\mathrm{N}=134)$ was recorded, with five countries achieving the WHO target of surveillance index ( $\geq 0.8$ ). In 2019 and 2020, the number of countries that obtained an acceptable surveillance index decreased from two to zero, respectively. In the year 2020, the lowest number of AFP cases was reported $(\mathrm{N}=56)$. Out of 554 notified AFP cases, 479 were children aged 0-15 years. As shown in Figure 1, more than 50\% of AFP cases belonged to the 1-3 years and 4-6 years age groups.

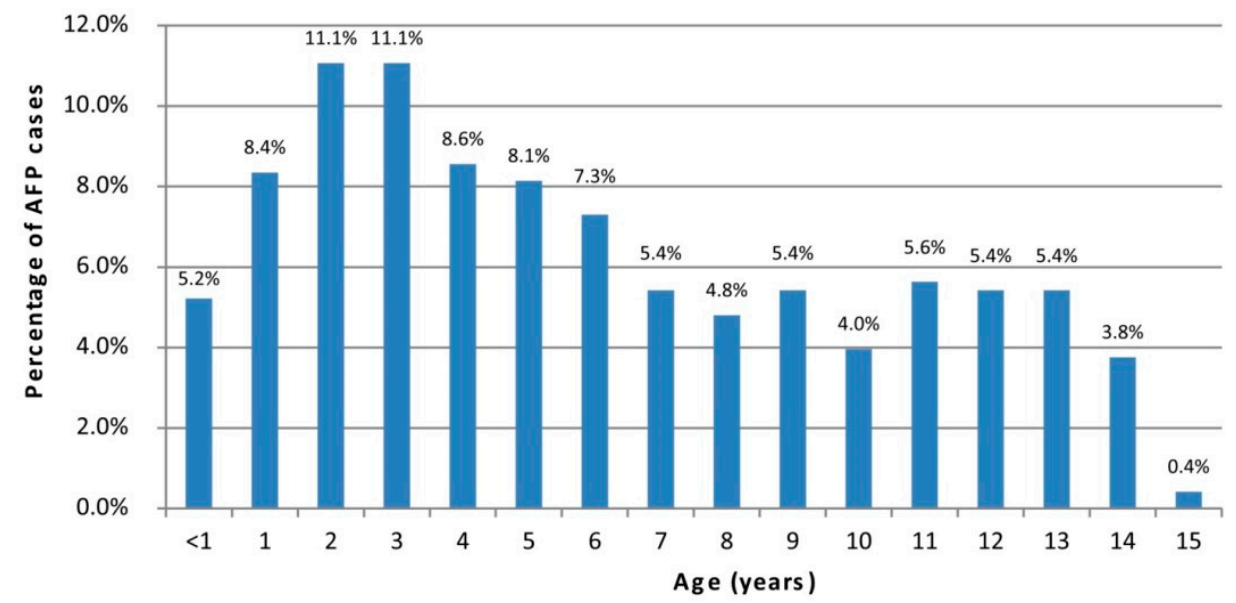

Figure 1. Percentage of AFP cases by age.

\subsection{Polio Vaccination Coverage}

Figure 2 shows the percentage of children aged 12-23 months who received three doses of polio vaccine (OPV or IPV). Italy, Albania, Greece, Malta, Serbia, and Kosovo reported, at least since 2017, polio vaccination coverage $\geq 95 \%$. Suboptimal coverage was reported in Bosnia and Herzegovina, Bulgaria, Montenegro, and North Macedonia.

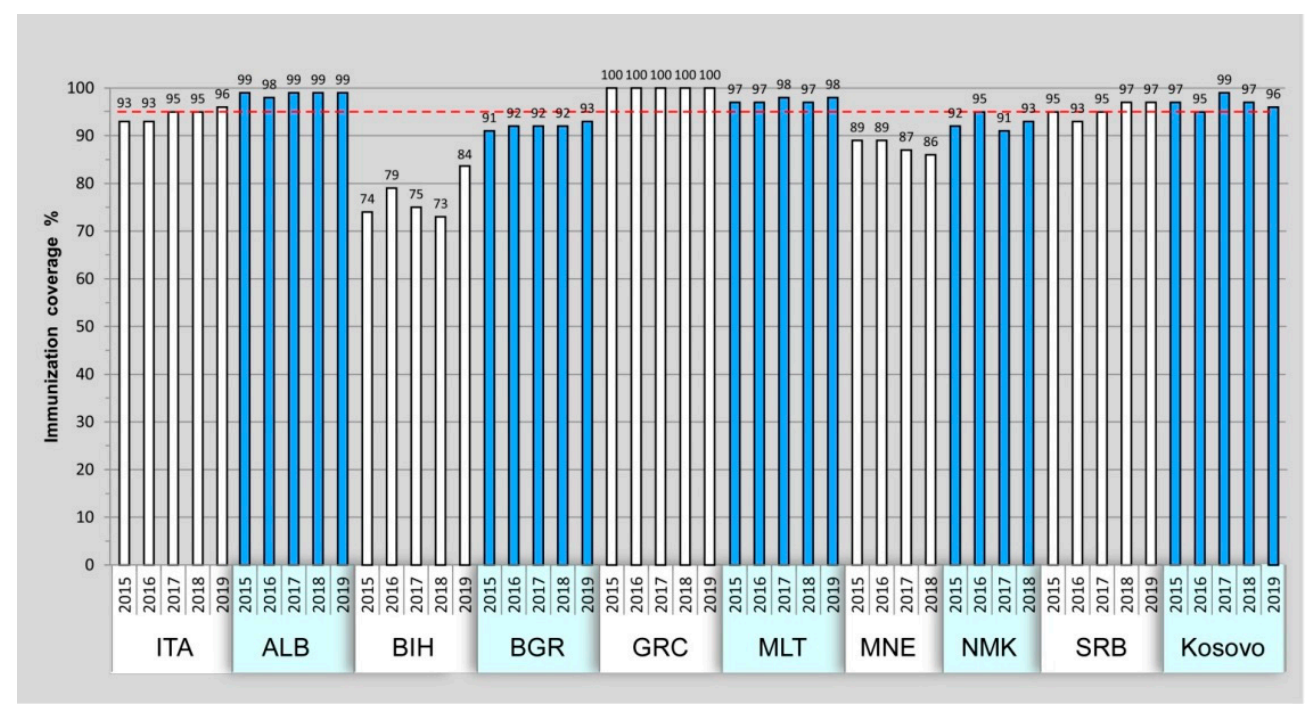

Figure 2. Three doses of polio vaccination coverage from 2015 to 2019 among children aged 12-23 months. Reference value of $95 \%$ coverage is shown by red line. Montenegro and North Macedonia lack data from 2019. 
Table 1. Six years of AFP surveillance data from Italy, Serbia, Bosnia and Herzegovina, Montenegro, Bulgaria, Kosovo, Albania, North Macedonia, Malta, and Greece.

\begin{tabular}{|c|c|c|c|c|c|c|c|c|c|c|c|c|}
\hline Year & Inicators & Albania & $\begin{array}{l}\text { Bosnia and } \\
\text { Herzegovina }\end{array}$ & Bulgaria & Greece & Italy & Malta & Montenegro & Serbia & $\begin{array}{c}\text { North } \\
\text { Macedonia }\end{array}$ & Kosovo & TOTAL \\
\hline \multirow{4}{*}{2015} & $\begin{array}{c}\text { No. of } \\
\text { AFP Cases }\end{array}$ & 5 & 3 & 12 & 18 & 44 & 0 & 1 & 11 & 2 & 0 & 96.00 \\
\hline & $\begin{array}{l}\text { non-Polio } \\
\text { AFP rate * }\end{array}$ & 0.77 & 0.6 & 1.13 & 1.05 & 0.51 & 0 & 0.86 & 0.65 & 0.59 & 0 & 0.65 \\
\hline & $\begin{array}{c}\text { \% with } \\
2 \text { stool } \\
\text { spec. }{ }^{* *}\end{array}$ & $100 \%$ & $67 \%$ & $100 \%$ & $94 \%$ & $70 \%$ & N.A. & $100 \%$ & $73 \%$ & $100 \%$ & N.A. & $88.00 \%$ \\
\hline & $\begin{array}{l}\text { Surveillance } \\
\text { index }\end{array}$ & 0.77 & 0.4 & 1 & 0.94 & 0.36 & 0 & 0.86 & 0.47 & 0.59 & 0 & 0.53 \\
\hline \multirow{4}{*}{2016} & $\begin{array}{l}\text { No. of } \\
\text { AFP Cases }\end{array}$ & 8 & 10 & 17 & 18 & 68 & 0 & 2 & 10 & 3 & 0 & 134.00 \\
\hline & $\begin{array}{l}\text { non-Polio } \\
\text { AFP rate * }\end{array}$ & 1.25 & 2.27 & 1.6 & 1.05 & 0.79 & 0 & 1.72 & 0.48 & 0.9 & 0 & 0.90 \\
\hline & $\begin{array}{l}\text { \% with } \\
2 \text { stool } \\
\text { spec. } * *\end{array}$ & $100 \%$ & $100 \%$ & $100 \%$ & $100 \%$ & $69 \%$ & N.A. & $100 \%$ & $90 \%$ & $100 \%$ & N.A. & $94.14 \%$ \\
\hline & $\begin{array}{l}\text { Surveillance } \\
\text { index }\end{array}$ & 1 & 1 & 1 & 1 & 0.54 & 0 & 1 & 0.43 & 0.9 & 0 & 0.77 \\
\hline \multirow{4}{*}{2017} & $\begin{array}{c}\text { No. of } \\
\text { AFP Cases }\end{array}$ & 7 & 5 & 5 & 10 & 49 & 0 & 2 & 10 & 3 & 1 & 92.00 \\
\hline & $\begin{array}{l}\text { non-Polio } \\
\text { AFP rate * }\end{array}$ & 1.12 & 1.26 & 0.47 & 0.58 & 0.57 & 0 & 1.74 & 0.6 & 0.91 & 2 & 0.62 \\
\hline & $\begin{array}{l}\text { \% with } \\
2 \text { stool } \\
\text { spec. } * *\end{array}$ & $100 \%$ & $100 \%$ & $60 \%$ & $100 \%$ & $67 \%$ & N.A. & $100 \%$ & $30 \%$ & $100 \%$ & $100 \%$ & $82.13 \%$ \\
\hline & $\begin{array}{l}\text { Surveillance } \\
\text { index }\end{array}$ & 1 & 1 & 0.28 & 0.58 & 0.38 & 0 & 1 & 0.18 & 0.91 & 1 & 0.45 \\
\hline \multirow{4}{*}{2018} & $\begin{array}{l}\text { No. of } \\
\text { AFP Cases }\end{array}$ & 2 & 1 & 10 & 18 & 39 & 0 & 1 & 8 & 3 & 0 & 82.00 \\
\hline & $\begin{array}{l}\text { non-Polio } \\
\text { AFP rate * }\end{array}$ & 0.32 & 0.43 & 0.94 & 1.1 & 0.45 & 0 & 0.88 & 0.49 & 0.92 & 0 & 0.55 \\
\hline & $\begin{array}{l}\text { \% with } \\
2 \text { stool } \\
\text { spec. } * *\end{array}$ & $100 \%$ & $100 \%$ & $90 \%$ & $89 \%$ & $67 \%$ & N.A. & $100 \%$ & $88 \%$ & $100 \%$ & N.A. & $91.75 \%$ \\
\hline & $\begin{array}{l}\text { Surveillance } \\
\text { index } * * *\end{array}$ & 0.32 & 0.43 & 0.84 & 0.89 & 0.3 & 0 & 0.88 & 0.43 & 0.92 & 0 & 0.44 \\
\hline \multirow{4}{*}{2019} & $\begin{array}{c}\text { No. of } \\
\text { AFP Cases }\end{array}$ & 0 & 2 & 12 & 11 & 53 & 1 & 0 & 12 & 3 & 0 & 94.00 \\
\hline & $\begin{array}{l}\text { non-Polio } \\
\text { AFP rate * }\end{array}$ & 0 & 0.43 & 1.12 & 0.69 & 0.62 & 1.59 & 0 & 0.74 & 0.93 & 0 & 0.63 \\
\hline & $\begin{array}{l}\text { \% with } \\
2 \text { stool } \\
\text { spec. } * *\end{array}$ & N.A. & $100 \%$ & $100 \%$ & $100 \%$ & $68 \%$ & $100 \%$ & $0 \%$ & $100 \%$ & $100 \%$ & N.A. & $94.67 \%$ \\
\hline & $\begin{array}{l}\text { Surveillance } \\
\text { index }\end{array}$ & 0 & 0.43 & 1 & 0.69 & 0.42 & 1 & 0 & 0.74 & 0.93 & 0 & 0.52 \\
\hline \multirow{4}{*}{2020} & $\begin{array}{c}\text { No. of } \\
\text { AFP Cases }\end{array}$ & 2 & 1 & 6 & 10 & 31 & 0 & 0 & 5 & 1 & 0 & 56.00 \\
\hline & $\begin{array}{l}\text { non-Polio } \\
\text { AFP rate * }\end{array}$ & 0.33 & 0.22 & 0 & 0.63 & 0.27 & 0 & 0 & 0.06 & 0.31 & 0 & 0.38 \\
\hline & $\begin{array}{c}\text { \% with } \\
2 \text { stool } \\
\text { spec. }{ }^{* *}\end{array}$ & $100 \%$ & $100 \%$ & $100 \%$ & $50 \%$ & $52 \%$ & N.A. & $0 \%$ & $60 \%$ & $100 \%$ & N.A. & $80.29 \%$ \\
\hline & $\begin{array}{l}\text { Surveillance } \\
\text { index }\end{array}$ & 0.33 & 0.22 & 0 & 0.32 & 0.14 & 0 & 0 & 0.04 & 0.31 & 0 & 0.23 \\
\hline
\end{tabular}

${ }^{*}$ Annualized rate per 100,000 children under the age of 15. Bold = meeting WHO target of 1.0. ${ }^{* *}$ Two stool specimens collected at least $24 \mathrm{~h}$ apart within 14 days of onset of paralysis and adequately shipped to the laboratory. Bold $=$ meeting WHO target of $80 \%$. *** Surveillance Index $=$ non-polio AFP rate (not to exceed the target) $\times$ percent adequate stool collection. Bold $=0.8$. 


\subsection{Supplementary Surveillance Systems}

Five countries performed supplementary surveillance activities in addition to AFP surveillance. As shown in Table 2, Italy and Malta analyzed environmental samples to monitor a potential circulation of poliovirus. Greece performed both enterovirus and environmental surveillance in 2018 and 2019. Enterovirus surveillance was constantly performed by Serbia from 2015 to 2020 and by Albania from 2015 to 2019. Italy and Albania were the countries that analyzed the majority of samples for environmental, and for enteroviruses surveillances, respectively (Italy, $\mathrm{N}=1386$; Albania, $\mathrm{N}=555$ ).

Table 2. Number of samples analyzed by supplementary surveillance activities per country, 2015-2020.

\begin{tabular}{|c|c|c|c|c|c|c|}
\hline \multirow{2}{*}{ Year } & \multirow{2}{*}{$\begin{array}{c}\text { Italy } \\
\text { Environmental }\end{array}$} & \multirow{2}{*}{$\begin{array}{c}\text { Albania } \\
\text { Enterovirus }\end{array}$} & \multicolumn{2}{|c|}{ Greece } & \multirow{2}{*}{$\begin{array}{c}\text { Malta } \\
\text { Environmental }\end{array}$} & \multirow{2}{*}{$\begin{array}{c}\text { Serbia } \\
\text { Enterovirus }\end{array}$} \\
\hline & & & Enterovirus & Environmental & & \\
\hline 2015 & 206 & 95 & & & & 17 \\
\hline 2016 & 194 & 119 & & & & 44 \\
\hline 2017 & 231 & 104 & 88 & 8 & 3 & 17 \\
\hline 2018 & 359 & 102 & 151 & 15 & & 30 \\
\hline 2019 & 198 & 135 & 3 & 22 & 3 & 75 \\
\hline 2020 & 198 & & & & 3 & 2 \\
\hline Total & 1386 & 555 & 242 & 45 & 9 & 185 \\
\hline
\end{tabular}

\subsection{EV Isolation and Typing}

Sabin-like poliovirus type 2 and 3 were isolated during AFP surveillance in 2017 and 2016, as already described. In particular, one Sabin-like poliovirus type 3 was isolated in 2017 from a child resident in Albania and two Sabin-like poliovirus type 2 were found in two children in Bosnia and Herzegovina in 2016 [19].

Two Sabin-like PV type 3 were isolated in 2015 and one in 2017 from sewage samples collected within the environmental surveillance in Italy.

A total of 794 non-polio enteroviruses (NPEVs) were identified in samples collected through AFP, enterovirus and environmental surveillance. Most of the NPEVs were identified in Italy through environmental surveillance $(\mathrm{N}=587 ; 17.08 \%)$ followed by those isolated in Albania ( $\mathrm{N}=41 ; 1.19 \%)$, Greece $(\mathrm{N}=79 ; 2.30 \%)$, and Serbia $(\mathrm{N}=27 ; 0.79 \%)$ during enterovirus surveillance activities. Fewer NPEVs were isolated in the context of AFP surveillance (Figure 3).

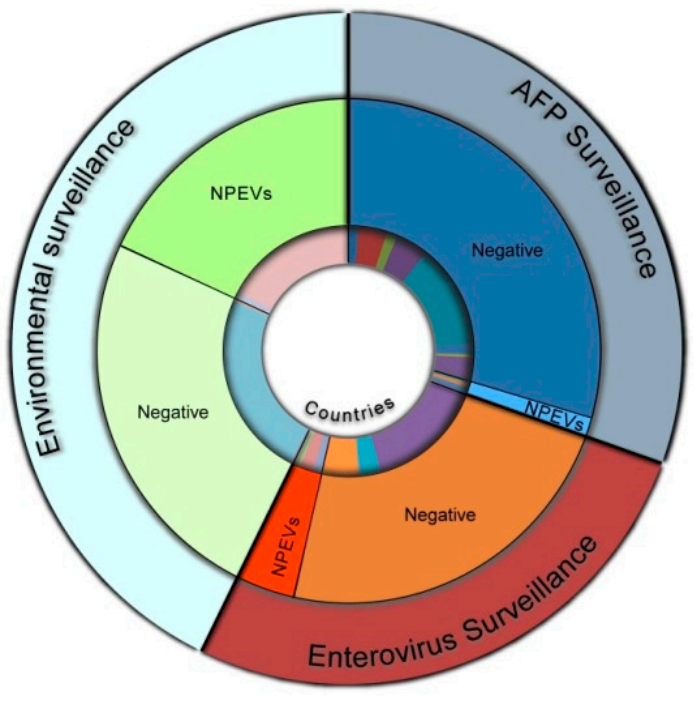

\begin{tabular}{|c|c|c|c|c|c|}
\hline \multicolumn{3}{|c|}{$\begin{array}{l}\text { AFP Surveillance. } \\
\text { Negative samples: } \mathrm{N}=985 ; 28.67 \%\end{array}$} & \multicolumn{3}{|c|}{$\begin{array}{l}\text { AFP Surveillance. } \\
\text { NPEV samples: } \mathrm{N}=29 ; 0.84 \%\end{array}$} \\
\hline ALB & $N=42$ & $1.22 \%$ & BGR & $N=4$ & $0.12 \%$ \\
\hline BGR & $N=124$ & $3.61 \%$ & GRC & $N=8$ & $0.23 \%$ \\
\hline $\mathrm{BIH}$ & $N=46$ & $1.34 \%$ & $\because \pi \mathrm{A}$ & $N=14$ & $0.41 \%$ \\
\hline GRC & $N=141$ & $4.10 \%$ & MNE & $N=1$ & $0.03 \%$ \\
\hline I & $N=445$ & $12.95 \%$ & WRB & $\mathrm{N}=2$ & $0.06 \%$ \\
\hline Kosovo & $N=2$ & $0.06 \%$ & & & \\
\hline MKD & $N=44$ & $1.28 \%$ & & & \\
\hline MLT & $N=2$ & $0.06 \%$ & & & \\
\hline MNE & $N=13$ & $0.38 \%$ & & & \\
\hline SRB & $\mathrm{N}=126$ & $3.67 \%$ & & & \\
\hline \multicolumn{3}{|c|}{$\begin{array}{l}\text { Enterovirus Surveillance. } \\
\text { Negative samples: } \mathrm{N}=835 ; 23.01 \%\end{array}$} & \multicolumn{3}{|c|}{$\begin{array}{l}\text { Enterovirus Surveillance. } \\
\text { NPEV samples: } N=147 ; 4.28 \%\end{array}$} \\
\hline ALB & $N=514$ & $14.96 \%$ & $\approx \mathrm{ALB}$ & $N=41$ & $1.19 \%$ \\
\hline GRC & $N=163$ & $4.74 \%$ & $\| \mathrm{GRC}$ & $N=79$ & $2.30 \%$ \\
\hline SRB & $N=158$ & $4.60 \%$ & SRB & $N=27$ & $0.79 \%$ \\
\hline \multicolumn{3}{|c|}{$\begin{array}{l}\text { Environmental Surveillance. } \\
\text { Negative samples: } \mathrm{N}=822 ; 24.70 \%\end{array}$} & \multicolumn{3}{|c|}{$\begin{array}{l}\text { Environmental Surveillance. } \\
\text { NPEV samples: } N=618 ; 17.99 \%\end{array}$} \\
\hline$=\mathrm{GRC}$ & $N=15$ & $0.44 \%$ & $\| \mathrm{GRC}$ & $N=30$ & $0.87 \%$ \\
\hline$\pi \mathrm{A}$ & $N=799$ & $23.25 \%$ & $\Pi \pi \mathrm{A}$ & $N=587$ & $17.08 \%$ \\
\hline $\mathrm{MLT}$ & $N=8$ & $0.23 \%$ & $\mathrm{MLT}$ & $N=1$ & $0.03 \%$ \\
\hline
\end{tabular}

Figure 3. Number and relative percentage of NPEVs identified by type of surveillance and country, 2015-2020. 
Out of 794 NPEVs identified, 243 were molecularly typed. A total of 22 viral strains were typed and isolated through AFP surveillance activities, while 72 and 149 were typed using enterovirus and environmental surveillance, respectively (Table 3). In sewage samples collected in Italy through environmental surveillance, the most frequently detected NPEVs were human echovirus $7(\mathrm{~N}=36)$, human coxsackievirus B5 $(\mathrm{N}=32)$, and human coxsackievirus $\mathrm{B} 4(\mathrm{~N}=17)$. Among the strains isolated within the enterovirus surveillance, most of them were typed as human coxsackievirus A24 (Greece; $\mathrm{N}=21$ ) and human echovirus 11 (Serbia; $\mathrm{N}=9$ ). Four human enterovirus 71 strains, known to cause epidemics of severe neurological disease and hand, foot and mouth disease in children $[7,8]$, were isolated in Greece in two AFP cases.

Table 3. Number and percentage of typed NPEVs by surveillance and countries.

\begin{tabular}{|c|c|c|c|}
\hline $\begin{array}{c}\text { Surveillance (Number of } \\
\text { NPEVs Typed) }\end{array}$ & Genotypes by Countries & Number of Genotypes & $\begin{array}{c}\text { Percentage of Genotypes } \\
\text { by Countries }\end{array}$ \\
\hline \multirow{14}{*}{$\operatorname{AFP}(\mathrm{N}=22)$} & BGR & 2 & \\
\hline & Human_echovirus_30 & 2 & $100.00 \%$ \\
\hline & GRC & 8 & \\
\hline & Human_coxsackievirus_A16 & 2 & $25.00 \%$ \\
\hline & Human_echovirus_18 & 2 & $25.00 \%$ \\
\hline & Human_enterovirus_71 & 4 & $50.00 \%$ \\
\hline & ITA & 10 & \\
\hline & Human_coxsackievirus_B4 & 2 & $20.00 \%$ \\
\hline & Human_echovirus_11 & 2 & $20.00 \%$ \\
\hline & Human_echovirus_25 & 2 & $20.00 \%$ \\
\hline & Human_echovirus_6 & 4 & $40.00 \%$ \\
\hline & SRB & 2 & \\
\hline & Human_coxsackievirus_B1-6 & 1 & $50.00 \%$ \\
\hline & Human_echovirus_21 & 1 & $50.00 \%$ \\
\hline \multirow{18}{*}{ Enterovirus $(\mathrm{N}=72)$} & $\begin{array}{c}\text { GRC } \\
\text { Human_coxsackievirus_A1 }\end{array}$ & $\begin{array}{c}63 \\
1\end{array}$ & $1.59 \%$ \\
\hline & Human_coxsackievirus_A8 & 2 & $3.17 \%$ \\
\hline & Human_coxsackievirus_A11 & 8 & $12.70 \%$ \\
\hline & Human_coxsackievirus_A16 & 5 & $7.94 \%$ \\
\hline & Human_coxsackievirus_A17 & 2 & $3.17 \%$ \\
\hline & Human_coxsackievirus_A19 & 4 & $6.35 \%$ \\
\hline & Human_coxsackievirus_A20 & 5 & $7.94 \%$ \\
\hline & Human_coxsackievirus_A24 & 21 & $33.33 \%$ \\
\hline & Human_coxsackievirus_B5 & 2 & $3.17 \%$ \\
\hline & Human_echovirus_21 & 2 & $3.17 \%$ \\
\hline & Human_echovirus_25 & 2 & $3.17 \%$ \\
\hline & Human_echovirus_29 & 2 & $3.17 \%$ \\
\hline & Human_echovirus_30 & 2 & $3.17 \%$ \\
\hline & Human_enterovirus_A76 & 1 & $1.59 \%$ \\
\hline & Human_enterovirus_B81 & 1 & $1.59 \%$ \\
\hline & Human_enterovirus_C & 3 & $4.76 \%$ \\
\hline & SRB & 9 & \\
\hline & Human_echovirus_11 & 9 & $100.00 \%$ \\
\hline
\end{tabular}


Table 3. Cont.

\begin{tabular}{|c|c|c|c|}
\hline $\begin{array}{c}\text { Surveillance (Number of } \\
\text { NPEVs Typed) }\end{array}$ & Genotypes by Countries & Number of Genotypes & $\begin{array}{c}\text { Percentage of Genotypes } \\
\text { by Countries }\end{array}$ \\
\hline \multirow{25}{*}{ Environmental $(\mathrm{N}=149)$} & GRC & 17 & \\
\hline & Human_coxsackievirus_A11 & 2 & $11.76 \%$ \\
\hline & Human_coxsackievirus_A13 & 4 & $23.53 \%$ \\
\hline & Human_coxsackievirus_A24 & 4 & $23.53 \%$ \\
\hline & Human_echovirus_11 & 3 & $17.65 \%$ \\
\hline & Human_echovirus_30 & 3 & $17.65 \%$ \\
\hline & Human_echovirus_9 & 1 & $5.88 \%$ \\
\hline & ITA & 132 & \\
\hline & Human_coxsackievirus_A4 & 1 & $0.76 \%$ \\
\hline & Human_coxsackievirus_A5 & 2 & $1.52 \%$ \\
\hline & Human_coxsackievirus_B2 & 1 & $0.76 \%$ \\
\hline & Human_coxsackievirus_B3 & 5 & $3.79 \%$ \\
\hline & Human_coxsackievirus_B4 & 17 & $12.88 \%$ \\
\hline & Human_coxsackievirus_B5 & 32 & $24.24 \%$ \\
\hline & Human_echovirus_1 & 6 & $4.55 \%$ \\
\hline & Human_echovirus_11 & 9 & $6.82 \%$ \\
\hline & Human_echovirus_12 & 1 & $0.76 \%$ \\
\hline & Human_echovirus_13 & 1 & $0.76 \%$ \\
\hline & Human_echovirus_14 & 3 & $2.27 \%$ \\
\hline & Human_echovirus_18 & 1 & $0.76 \%$ \\
\hline & Human_echovirus_19 & 1 & $0.76 \%$ \\
\hline & Human_echovirus_3 & 3 & $2.27 \%$ \\
\hline & Human_echovirus_30 & 2 & $1.52 \%$ \\
\hline & Human_echovirus_6 & 11 & $8.33 \%$ \\
\hline & Human_echovirus_7 & 36 & $27.27 \%$ \\
\hline TOTAL & & 243 & \\
\hline
\end{tabular}

\section{Discussion}

The aim of the AFP surveillance system is to promptly detect any polio suspected case and to adopt the adequate control measures to prevent wild poliovirus (WPV) and cVDPV spread. AFP surveillance indicators are used to monitor the quality of the surveillance activities and the target value is defined by the WHO to evaluate the surveillance performance of each country. The SI indicator combines the non-polio AFP rate (WHO target value $\geq 1$ ) and the percentage of adequate stool specimens (WHO target value $\geq 80 \%$ ) and represents one of the most significant performance parameters. The WHO has set the SI value $\geq 0.8$ as a target to define an adequate surveillance performance.

Considering the overall SI reported in this analysis, 18/60 values reached the WHO target. In 2019, only two countries, Bulgaria and North Macedonia, reported a surveillance index $\geq 0.8$ and in 2020 none of the countries reached the target value. The low values of SI are mainly due to low values of non-polio AFP rate rather than due to the percentage of adequate stool specimens. In fact, while in more than half of percentage adequate specimens data reached the WHO target, there were only 11/60 AFP rate values $\geq 0.1$. Underreporting of AFP cases can be explained by a change in perceived health priorities and decreasing attention on polio, due to the long-term absence of circulating polioviruses. Indeed, the last case of polio in this list of countries occurred in three children in Bulgaria in 2001, where WPV1 circulation was reported in susceptible children living in a low vaccination coverage area [23]. As shown by the number and the relative percentage of samples analyzed by type of surveillance and countries, Albania and Italy have adopted enterovirus and environmental surveillances with 555 and 1386 samples analyzed in the period, respectively. In 2020, the COVID-19 emergency further contributed to the decrease of AFP reported cases in all of the countries. In fact, as shown by a study on the impact of 
the COVID-19 pandemic on global poliovirus surveillance, the number of reported AFP cases declined by $33 \%$ and the mean number of days between the second stool specimen collection and receipt by the laboratory increased up to $70 \%$ [24]. Our data reflect the negative impact of the pandemic emergency in the routine AFP surveillance: in 2020 all analyzed countries reported an AFP rate $<0.8$. Our findings also showed that the majority of AFP cases (52\%) were in age groups under 5 years. This is in line with findings from previous studies in Kenya, Ghana, Iran, Nigeria, and India [25-27].

Thanks to polio vaccines, the burden of disease has been strongly reduced over the years: since 1988, wild polio cases have dropped by 99.9\%, wild PV types 2 and 3 have been eradicated, and type 1 is currently endemic in only two countries-Afghanistan and Pakistan [17]. Since 2016, the trivalent OPV, containing all three types of Sabin strains, was replaced by bivalent OPV (bOPV; containing types 1 and 3 Sabin strains) and injectable inactivated poliovirus vaccine (IPV), containing antigens for all three PV types have been used in routine immunization programs worldwide [28]. Despite the efforts and results obtained by the GPEI, the presence of a cohort of unimmunized people led to an increase in the number of WPV1 cases in Afghanistan and Pakistan and cVDPV type 2 outbreaks.

Our vaccination coverage data highlighted some critical aspects: four countries (Bosnia and Herzegovina, Bulgaria, Montenegro, and North Macedonia) showed immunization under the reference value of $95 \%$ during the study period. In addition, it is very likely that the coverage values have dropped even more in 2020, in all countries, due to the COVID-19 pandemic.

Our data suggest that some countries are at a high risk of polio outbreak following a possible importation of WPV or emergence of cVDPV, due to a low immunity of the population [29]. Furthermore, as previously reported by the WHO, several middle-income countries remain at intermediate risk of polio transmission, as their vaccination coverage appears to be declining and due to the suboptimal quality of poliovirus surveillance [30].

In Italy, the vaccination coverage was enhanced by the introduction, in 2017, of the National Immunization Plan (https:/ / www.trovanorme.salute.gov.it/norme/dettaglioAtto? id=60201 (accessed on 23 December 2021)) that increased the number of mandatory vaccinations [31].

Environmental and enterovirus surveillance activities are adopted by many countries in support of the GPEI. However, although five countries reported data related to additional surveillance, only three reported systematic activities, suggesting that more efforts are needed in the implementation of other surveillance systems, which can provide an alert for a possible reintroduction of poliovirus. An infected person, even if they are asymptomatic, sheds large amounts of virus daily into the wastewater system for several weeks to months after infection [32]. Since PVs can persist in the environment for long periods, sewage screening can detect PV circulating in the community without clinical cases reported, especially in areas with high vaccination coverage with inactivated IPV. The usefulness of the environmental surveillance, as support to the AFP surveillance, has been demonstrated by several studies where PV was detected in the environment despite the absence of clinical cases in the population [33-36]. Another tool in support of the GPEI strategies is the enterovirus surveillance [14]. In the post-polio eradication era, enterovirus surveillance may provide an early warning system for a possible poliovirus reintroduction and for the detection and response to outbreaks of other potentially severe EVs, such as D68 and EV71.

Regarding the virus identification and typing data, no WPVs were isolated during the period. However, the isolation of two Sabin-like poliovirus type 2 strains in Bosnia and Herzegovina, one of them close to a VDPV, and the finding of a PV Sabin-like 3 virus in a child in Albania, requires particular attention. The genetic instability of Sabin strains permits occasional reversion to neurovirulence causing VAPP in vaccine recipients and infection in their unvaccinated contacts [37]. A low immunization coverage increases the risk of vaccine strains transmission leading to acquisition of new genetic variants resulting in the generation of new cVDPV [38]. 
Sabin-like PV type 3 was isolated in sewage samples of North Italy in 2015 and 2017. Since IPV completely replaced the OPV in Italy for safety reasons and risk-benefit considerations, the vaccine strains findings indicate the presence of people from regions in the world where OPV vaccination is still being used.

NPEVs identification data showed that a high proportion of them were detected in the environment when compared with AFP and enterovirus surveillances. These data reflect the biological characteristics of EV infections. EVs are transmitted from person-toperson through the fecal-oral and oral-oral routes and are shed into the environment, where they can remain infectious for a long period of time. It was estimated that the amount of EV excreted into stools can reach the maximal amounts of $10^{7}$ infectious doses/day per person [32]. For these reasons, environmental and, in particular, sewage sites represent biological collectors where EVs are present in abundance. On the contrary, although the screening of AFP cases is the gold standard to highlight a possible PV circulation and enterovirus surveillance represents a valid support to PV eradication activities, there are two main reasons for the few numbers of NPEVs isolated: the paralysis can be frequently caused by non-infectious diseases, such as Guillain-Barre Syndrome, and the enterovirus surveillance is based on clinical signs and symptoms common to numerous viral and bacterial etiological agents.

NPEV typing data suggest a heterogeneous presence of viral strains: over the years numerous genotypes of coxsackievirus and echovirus have been isolated in all types of surveillance. However, our study has several limitations. The lacking of systematic and homogeneous enterovirus and environmental surveillance systems in the analyzed countries, and the small number of isolated and typed NPEVs in AFP and enterovirus surveillance, does not allow us to draw conclusions about the predominant genotypes. As reported by previous studies, typing of environmental NPEVs isolated in Italy showed the predominant circulation of echovirus 7, coxsackievirus B5, and coxsackievirus B4 [39,40]. Coxsackievirus, echovirus, and other EVs, such as D68 and EV71, cause severe diseases, particularly among young people, and represent a public health issue in industrialized countries. Environmental surveillance may provide an early detection system for human enteric pathogens and the isolated and typed virus may help in depicting the predominant circulating strains.

\section{Conclusions}

In conclusion, our study describes the main results from surveillance activities in different countries aimed at maintaining the polio-free status. The monitoring of the real burden of EV diseases, including polio, is crucial to maintain the polio-free status. Efficient surveillance systems and high vaccination coverage are the two pillars to avoid polio reintroduction and spreading, and to respond to VDPV outbreaks in a timely manner.

Author Contributions: Conceptualization, G.B. and P.S.; Data curation, S.F. (Stefano Fontana), M.K., J.A., M.B., M.M., L.N.-G., A.M., A.V.-K., L.G., P.K.-G., C.B., J.M., J.P., S.F.-V., P.M.O., A.D., R.O., A.S. and E.S.; Formal analysis, S.F. (Stefano Fontana), S.F. (Stefano Fiore), C.A., M.P., M.K., J.A., M.B., M.M., L.N.-G., A.M., A.V.-K., L.G., P.K.-G., C.B., J.M., J.P. and S.F.-V.; Funding acquisition, P.S.; Investigation, G.B.; Supervision, P.S.; Writing—original draft, S.F. (Stefano Fontana); Writing-review \& editing, P.S. All authors will be informed about each step of manuscript processing including submission, revision, revision reminder, etc. via emails. All authors have read and agreed to the published version of the manuscript.

Funding: This work was supported by a WHO grant "Full providing of laboratory support for surveillance of polioviruses in Acute Flaccid Paralysis Cases and in the Environment from specified European Countries" (June 2018-November 2019) and by the Italian Ministry of Health CCM 4S11 Grant, "Monitoraggio della circolazione di enterovirus a supporto delle attività di sorveglianza per il mantenimento dello status polio-free" (February 2019-Febraury 2021).

Institutional Review Board Statement: Not applicable.

Informed Consent Statement: Not applicable. 
Data Availability Statement: Not applicable.

Acknowledgments: We gratefully acknowledge the collaborators of AFP surveillance activities: Daniela Lombardi-Regional Reference Service of Epidemiology for the Surveillance, Prevention, and Control of Infectious Diseases SeREMI ASL AL, Alessandria; Sandro Binda, Laura Pellegrinelli, Valeria Primache-Department of Biomedical Sciences for Health, University of Milan; Silvia Spertini-Hygiene and Public Health Service, Azienda Sanitaria dell'Alto Adige, Bolzano; Valter Carraro-Department of Hygiene and Public Health, Azienda Autonoma Sanitaria della Provincia di Trento, Trento; Francesca Russo-Prevention Department, Veneto Regional Health Authority, Venice; Francesca Zanella Department of Public Health and Screening, Veneto Region, Venezia; Silvio Brusaferro SOC Accreditamento, Gestione del Rischio Clinico e Valutazione delle Performance Sanitarie Azienda Sanitaria Universitaria Friuli Centrale-Istituto Superiore di Sanità, Cecilia Smaniotto SOC Accreditamento, Gestione del Rischio Clinico e Valutazione delle Performance Sanitarie Azienda Sanitaria Universitaria Friuli Centrale; Filippo Ansaldi, Paola Canepa- Department of Health Sciences, University of Genoa; Andre Orsi Department of Health Sciences (DISSAL), Postgraduate School of Public Health, University of Genoa; Licia Veronesi, Paola Affanni, Roberta Zoni-Department of Medicine and Surgery, University of Parma; Guglielmo Bonaccorsi, Chiara Lorini-Department of Health Sciences, University of Florence; Barbara Camilloni-Department of Medicine, Università degli Studi di Perugia; Marcello M. D'Errico Department of Biomedical Sciences and Public Health, Polytechnic University of Marche, Ancona; Francesco Vairo-National Institute for Infectious Diseases, Lazzaro Spallanzani, IRCCS, Rome; Benita Capannolo-ASL AvezzanoSulmona-L'Aquila, Department of Prevention and Public Health; Guido Grasso-Department of Medicine and of Health Sciences, University of Molise, Campobasso; Maria Triassi, Francesca Pennino Department of Public Health, University of Napoli "Federico II", Napoli; Cinzia Germinario, Angela M. V. Larocca,-Department of Biomedical Science and Human Oncology, "Aldo Moro" University of Bari; Michele Labianca Unit of Hygiene, Epidemiology and Public Health, ASL-Potenza; Anna Domenica Mignuoli-Dipartimento Tutela della Salute regione Calabria; Giovanni Giammanco, Simona De Grazia Department of Health Promotion, Mother and Child Care and Internal Medicine 'G. D'Alessandro', University of Palermo; Paolo Castiglia, Andrea Cossu Department of Biomedical Sciences, University of Sassari.

Conflicts of Interest: The authors declare that there are no conflict of interest.

\section{References}

1. Tapparel, C.; Siegrist, F.; Petty, T.J.; Kaiser, L. Picornavirus and enterovirus diversity with associated human diseases. Infect. Genet. Evol. 2013, 14, 282-293. [CrossRef] [PubMed]

2. $\quad$ E Midgley, S.; Christiansen, C.B.; Poulsen, M.W.; Hansen, C.H.; Fischer, T.K. Emergence of enterovirus D68 in Denmark, June 2014 to February 2015. Eurosurveillance 2015, 20, 21105. [CrossRef] [PubMed]

3. ECDC-Rapid Risk Assessment Enterovirus Detections Associated with Severe Neurological Symptoms in Children and Adults in European Countries. 2016. Available online: https:/ / ecdc.europa.eu/sites/portal/files/media/en/publications/Publications/ 07-06-2016-RRA-Enterovirus\%2071-Spain.pdf (accessed on 23 December 2021).

4. Broberg, E.K.; Simone, B.; Jansa, J.; The EU/EEA Member State Contributors. Upsurge in echovirus 30 detections in five EU/EEA countries, April to September, 2018. Eurosurveillance 2018, 23, 1800537. [CrossRef]

5. Kirolos, A.; Mark, K.; Shetty, J.; Chinchankar, N.; Mcdougall, C.; Eunson, P.; EV-D68 Associated AFM Study Group. Outcome of paediatric acute flaccid myelitis associated with enterovirus D68: A case series. Dev. Med. Child Neurol. 2019, 61, 376-380. [CrossRef] [PubMed]

6. Messacar, K.; Asturias, E.J.; Hixon, A.M.; Van Leer-Buter, C.; Niesters, H.G.M.; Tyler, K.L.; Abzug, M.J.; Dominguez, S.R. Enterovirus D68 and acute flaccid myelitis evaluating the evidence for causality. Lancet Infect. Dis. 2018, 18, e239-e247. [CrossRef]

7. Teoh, H.L.; Mohammad, S.S.; Britton, P.N.; Kandula, T.; Lorentzos, M.S.; Booy, R.; Jones, C.A.; Rawlinson, W.; Ramachandran, V.; Rodriguez, M.L.; et al. Clinical characteristics and functional motor outcomes of enterovirus 71 neurological disease in children. JAMA Neurol. 2016, 73, 300-307. [CrossRef] [PubMed]

8. Messacar, K.; Spence-Davizon, E.; Osborne, C.; Press, C.; Schreiner, T.L.; Martin, J.; Messer, R.; Maloney, J.; Burakoff, A.; Barnes, M.; et al. Clinical characteristics of enterovirus A71 neurological disease during an outbreak in children in Colorado, USA, in 2018: An observational cohort study. Lancet Infect. Dis. 2020, 20, 230-239. [CrossRef]

9. Maruo, Y.; Nakanishi, M.; Suzuki, Y.; Kaneshi, Y.; Terashita, Y.; Narugami, M.; Takahashi, M.; Kato, S.; Suzuki, R.; Goto, A.; et al. Outbreak of aseptic meningitis caused by echovirus 30 in Kushiro, Japan in 2017. J. Clin. Virol. 2019, 116, 34-38. [CrossRef] [PubMed] 
10. Nougairede, A.; Bessaud, M.; Thiberville, S.-D.; Piorkowski, G.; Ninove, L.; Zandotti, C.; Charrel, R.; Guilhem, N.; de Lamballerie, X. Widespread circulation of a new echovirus 30 variant causing aseptic meningitis and non-specific viral illness, South-East France, 2013. J. Clin. Virol. 2014, 61, 118-124. [CrossRef]

11. Kew, O.M.; Sutter, R.W.; de Gourville, E.M.; Dowdle, W.R.; Pallansch, M.A. Vaccine-derived polioviruses and the endgame strategy for global polio eradication. Annu. Rev. Microbiol. 2005, 59, 587-635. [CrossRef] [PubMed]

12. CDC. Global Immunization. Available online: https://www.cdc.gov/polio/what-we-do/index.htm. (accessed on 23 December 2021).

13. World Health Organization. WHO-Recommended Standards for Surveillance of Selected Vaccine Preventable Diseases; World Health Organization: Geneva, Switzerland, 1999.

14. CDC; WHO. Enterovirus Surveillance Guidelines. Guidelines for Enterovirus Surveillance in Support of the Polio Eradication Initiative; World Health Organization: Geneva, Switzerland, 2015.

15. Global Commission for the Certification of Poliomyelitis Eradication. 14th Meeting of the Global Commission for the Certification of Poliomyelitis Eradication (GCC) [Monograph on the Internet]; World Health Organization: Geneva, Switzerland, 2015. Available online: http:/ / polioeradication.org/wpcontent/uploads/2016/07/1Report.pdf (accessed on 10 September 2018).

16. Famulare, M. Has Wild Poliovirus Been Eliminated from Nigeria? PLoS ONE 2015, 10, e0135765. [CrossRef] [PubMed]

17. Hsu, C.H.; Kader, M.; Mahamud, A.; Bullard, K.; Jorba, J.; Agbor, J.; Safi, M.M.; Jafari, H.S.; Ehrhardt, D. Progress Toward Poliomyelitis Eradication-Pakistan, January 2018-September 2019. MMWR. Morb. Mortal. Wkly. Rep. 2019, 68, 1029-1033. [CrossRef] [PubMed]

18. ECDC. Outbreak of Circulating Vaccine-Derived Poliovirus Type 1(cVDPV1) in Ukraine; European Centre for Disease Prevention and Control: Solna, Swden, 2015. Available online: http:/ / ecdc.europa.eu/en/publications/publications / poliomyelitis-ukrainerapid-riskassessment-september-2015.pdf (accessed on 2 September 2015).

19. Fontana, S.; Buttinelli, G.; Fiore, S.; Mulaomerovic, M.; Aćimović, J.; Amato, C.; Delogu, R.; Rezza, G.; Stefanelli, P. Acute flaccid paralysis surveillance in Bosnia and Herzegovina: Recent isolation of two sabin like type 2 poliovirus. J. Med. Virol. 2017, 89, 1678-1681. [CrossRef]

20. WHO. Polio Laboratory Manual; WHO/IVB/04.10; World Health Organization: Geneva, Switzerland, 2004. Available online: http:/ /apps.who.int/iris/bitstream/10665/68762/1/WHO_IVB_04.10.pdf (accessed on 23 December 2021).

21. WHO. Supplement to the WHO Polio Laboratory Manual. 2014. Available online: https://polioeradication.org/wp-content/ uploads/2017/05/NewAlgorithmForPoliovirusIsolationSupplement1.pdf (accessed on 23 December 2021).

22. Burns, C.C.; Kilpatrick, D.R.; Iber, J.C.; Chen, Q.; Kew, O.M. Molecular Properties of Poliovirus Isolates: Nucleotide Sequence Analysis, Typing by PCR and Real-Time RT-PCR. Springer Protoc. Handb. 2016, 1387, 177-212. [CrossRef]

23. Kojouharova, M.; Zuber, P.L.F.; Gyurova, S.; Fiore, L.; Buttinelli, G.; Kunchev, A.; Vladimirova, N.; Korsun, N.; Filipova, R.; Boneva, R.; et al. Importation and circulation of poliovirus in Bulgaria in 2001. Bull. World Heal. Organ. 2003, 81, 476-481.

24. Zomahoun, D.J.; Burman, A.L.; Snider, C.J.; Chauvin, C.; Gardner, T.; Lickness, J.S.; Ahmed, J.A.; Diop, O.; Gerber, S.; Anand, A. Impact of COVID-19 Pandemic on Global Poliovirus Surveillance. MMWR. Morb. Mortal. Wkly. Rep. 2021, 69, 1648-1652. [CrossRef]

25. Tesfaye, B.; Sowe, A.; Kisangau, N.; Ogange, J.; Ntoburi, S.; Nekar, I.; Muitherero, C.; Camara, Y.; Gathenji, C.; Langat, D.; et al. An epidemiological analysis of Acute Flaccid Paralysis (AFP) surveillance in Kenya, 2016 to 2018. BMC Infect. Dis. 2020, $20,1-11$. [CrossRef]

26. Odoom, J.K.; Ntim, N.A.A.; Sarkodie, B.; Addo, J.; Minta-Asare, K.; Obodai, E.; Eshun, M.; Ahove, V.V.; Diamenu, S.; Adjabeng, M.; et al. Evaluation of AFP surveillance indicators in polio-free Ghana, 2009-2013. BMC Public Health 2014, 14, 687. [CrossRef] [PubMed]

27. Hamisu, A.W.; Johnson, T.M.; Craig, K.; Mkanda, P.; Banda, R.; Tegegne, S.G.; Oyetunji, A.; Ningi, N.; Mohammed, S.M.; Adamu, M.I.; et al. Strategies for improving polio surveillance performance in the security challenged Nigerian States of Adamawa, Borno, and Yobe during 2009-2014. J. Infect. Dis. 2016, 213 (Suppl. S3), S136-S139. [CrossRef] [PubMed]

28. Chard, A.N.; Datta, S.D.; Tallis, G.; Burns, C.C.; Wassilak, S.G.; Vertefeuille, J.F.; Zaffran, M. Progress Toward Polio EradicationWorldwide, January 2018-March 2020. MMWR. Morb. Mortal. Wkly. Rep. 2020, 69, 784-789. [CrossRef] [PubMed]

29. Snider, C.J.; Diop, O.M.; Burns, C.C.; Tangermann, R.H.; Wassilak, S.G.F. Surveillance systems to track progress toward polio eradication-worldwide, 2014-2015. Morb. Mortal. Wkly. Rep. 2016, 65, 346-351. [CrossRef]

30. World Health Organization Regional Office for Europe. 32nd Meeting of the European Regional Commission for Certification of Poliomyelitis Eradication. Report 2018. Available online: http:/ /www.euro.who.int/en/health-topics/communicable-diseases/ poliomyelitis / publications/2018/32nd-meeting-of-the-european-regional-commission-for-certification-of-poliomyelitiseradication-rcc-report-2018 (accessed on 24 October 2019).

31. Gianfredi, V.; D’Ancona, F.; Maraglino, F.; Cenci, C.; Iannazzo, S. Polio and measles: Reasons of missed vaccination in Italy, 2015-2017. Ann. Ig. Med. Prev. Comunita 2019, 31, 191-201.

32. Dowdle, W.; Van Der Avoort, H.; De Gourville, E.; Delpeyroux, F.; Desphande, J.; Hovi, T.; Martin, J.; Pallansch, M.; Kew, O.; Wolff, C. Containment of Polioviruses After Eradication and OPV Cessation: Characterizing Risks to Improve Management. Risk Anal. 2006, 26, 1449-1469. [CrossRef]

33. Manor, Y.; Handsher, R.; Halmut, T.; Neuman, M.; Bobrov, A.; Rudich, H.; Vonsover, A.; Shulman, L.; Kew, O.; Mendelson, E. Detection of poliovirus circulation by environmental surveillance in the absence of clinical cases in Israel and the Palestinian authority. J. Clin. Microbiol. 1999, 37, 1670-1675. [CrossRef] 
34. Shulman, L.M.; Gavrilin, E.; Jorba, J.; Martin, J.; Burns, C.C.; Manor, Y.; Moran-Gilad, J.; Sofer, D.; Hindiyeh, M.Y.; Gamzu, R.; et al. Molecular epidemiology of silent introduction and sustained transmission of wild poliovirus type 1, Israel, 2013. Eurosurveillance 2014, 19, 20709. [CrossRef]

35. Blomqvist, S.; El Bassioni, L.; El Maamoon Nasr, E.M.; Paananen, A.; Kaijalainen, S.; Asghar, H.; de Gourville, E.; Roivainen, M. Detection of Imported Wild Polioviruses and of Vaccine-Derived Polioviruses by Environmental Surveillance in Egypt. Appl. Environ. Microbiol. 2012, 78, 5406-5409. [CrossRef] [PubMed]

36. Blomqvist, S.; El Bassioni, L.; El Maamoon Nasr, E.M.; Paananen, A.; Kaijalainen, S.; Asghar, H.; de Gourville, E.; Roivainen, M. Highly divergent neurovirulent vaccine-derived polioviruses of all three serotypes are recurrently detected in Finnish sewage. Euro Surveill Bull. Eur. Mal. Transm. Eur. Commun. Dis. Bull. 2010, 15, 19566.

37. Platt, L.R.; Estívariz, C.F.; Sutter, R.W. Vaccine-associated paralytic poliomyelitis: A review of the epidemiology and estimation of the global burden. J. Infect. Dis. 2014, 210, S380-S389. [CrossRef] [PubMed]

38. Burns, C.C.; Diop, O.M.; Sutter, R.W.; Kew, O.M. Vaccine-derived polioviruses. J. Infect. Dis. 2014, 210, S283-S293. [CrossRef] [PubMed]

39. Delogu, R.; Battistone, A.; Buttinelli, G.; Fiore, S.; Fontana, S.; Amato, C.; Cristiano, K.; Gamper, S.; Simeoni, J.; Frate, R.; et al. Poliovirus and Other Enteroviruses from Environmental Surveillance in Italy, 2009-2015. Food Environ. Virol. 2018, 10, 333-342. [CrossRef] [PubMed]

40. Fontana, S.; Fiore, S.; Buttinelli, G.; Amato, C.; Veronesi, L.; Zoni, R.; Triassi, M.; Pennino, F.; Giammanco, G.M.; De Grazia, S.; et al. Molecular Characterization of Coxsackievirus B5 Isolates from Sewage, Italy 2016-2017. Food Environ. Virol. 2019, 11, 440-445. [CrossRef] [PubMed] 